UDC

\title{
NITROGEN-CARBON CIRCULATION IN AGROCENOSES WITH DIFFERENT FERTILIZATION SYSTEMS
}

\author{
O. V. Demydenko ${ }^{1}$, V. A. Velychko ${ }^{2}$ \\ ${ }^{1}$ Cherkasy State Agricultural Experimental Station, NSC "Institute of Agriculture", NAAS of Ukraine \\ 13, Dokuchaiev Str., Kholodnianske village, Smila District, Cherkasy Region, Ukraine \\ ${ }^{2}$ NSC "Institute for Soil Science and Agricultural Chemistry named after O.N. Sokolovsky" of NAAS \\ 2, Chaikovska Str., Kharkiv, Ukraine, 61024
}

E-mail:smilachiapv@ukr.net,agrovisnyk@ukr.net

Received .January 25, 2019 / Received February 22, 2019 / Accepted March 22, 2019

\begin{abstract}
Aim. To compare nitrogen-carbon circulation in organic and intense fertilization system in agrocenosis of a short crop rotation with grain and intertilled crops on podzolic highly-regraded low-humus chernozem in the Central Forest-Steppe of Ukraine. Methods. Summarization of the study results in the permanent field experiment, statistical method, dispersion method, correlation analysis of performance parameters, structures of phytomass, quality and quantity items of carbon and nitrogen balance. Results. In the organic system of fertilization, the removal of $\mathrm{N}$ increased to 0.25 units per capacity unit of nitrogen balance, which is 1.47 times higher, and the total loss of $\mathrm{N}$ increased 1.1 times ( 0.31 units per capacity unit of nitrogen balance) regarding the intense system of fertilization, but with lower values of balance items for nitrogen in the agrocenosis. Direct and strong correlation relationships were revealed between the yield of fodder units and the content of organic carbon in the structural components of the total phytomass: with organic carbon in the main products and root mass $-\mathrm{R}=0.86-0.88 \pm 0.02 ; \mathrm{R}^{2}=0.74-0.77$, and with the content of organic carbon in by-products and noncommodity total phytomass the relation to the yield of fodder units was on the level of direct mean correlation: $\mathrm{R}=0.58-0.65 \pm 0.02 ; \mathrm{R}^{2}=0.34-0.43$. The increase in the yield of fodder units is accompanied with the 1.32fold decrease in the nitrogen balance capacity regarding the intense system of fertilization. Conclusions. It was established that in case of organic system of fertilization the ratio of organic carbon and $\mathrm{N}$ in the agrocenosis of a short crop rotation is the most optimal and approximates 30:1, which is the most profitable for humification of by-products and decrease in the intensity of humus mineralization. Balance capacity is a restrictive factor in the circulation of organic carbon and $\mathrm{N}$ at the organic fertilization system, as it may considerably concede the balance capacity of organic carbon and $\mathrm{N}$ at the intense fertilization system, which had a negative impact on the performance of crop rotation.
\end{abstract}

Keywords: balance of organic carbon and nitrogen, balance capacity, performance, short crop rotation, correlation analysis.

DOI:

\section{INTRODUCTION}

The issue of transforming organic carbon, the dynamics, functions and regulation of flows in the soil-plant-atmosphere system at organic and intense fertilization system are urgent approaches of agrochemistry, and the increase in reserves of organic carbon, accessible for microorganisms, at different fertilization systems may be an efficient way of optimizing nitrogen regime of chernozem due to optimi-

(C) O. V. DEMYDENKO, V. A. VELYCHKO, 2019 zation of balanced carbon-nitrogen interactions [1-5]. The shortage of active organic substance in soil is one of the reasons for low content of microbial biomass and poor recirculating activity of nitrogen at different fertilization systems, which is excluded from the circulation and removed from the agrocenosis [6-8]. Carbon is a relevant element of nutrition for agricultural crops, it is a component of soil organic substance - a natural source of supplying plants with mineral nutrition elements, it controls the processes of nitrogen-fixation, denitrification, mineralization and 
immobilization of nitrogen, and is a source of energy for microorganisms [9-11].

Fresh organic matter is the main limiting factor of mineral nutrition for agricultural crops, and thus is the foundation of optimizing properties and regimes of chernozem - a direct dependence between the content of organic carbon in soil and the volume of yield at different fertilization systems. Beyond the limits of critical (threshold) level of organic carbon content, the yield capacity does not depend on providing soil with organic matter [12-19].

The urgent issue is supporting a specific level of providing both the intense and organic systems of fertilization with organic carbon of potentially mineralizing organic matter, ensuring the equivalent amount of carbon of fresh organic matter with nitrogen, which is a key condition for harmonization of mineralizationimmobilization circulation of nitrogen in agrocenosis and removing the asynchrony between the formation of nitrogen in soil and its consumption [20-23]. The values of gross- and net-mineralized nitrogen in chernozem should correlate with the content of potentially mineralized (active) organic substance, thus, the value of balance capacity of organic carbon is a feature of the activity of nitrogen circulation in agrocenosis at different fertilization systems and formation of agrocenosis performance [24-30].

The aim of the study was to determine normative parameters of nitrogen-carbon circulation and comparative regularities of forming the performance of a short crop rotation with grain and intertilled crops at intense and organic systems of fertilization.

\section{MATERIALS AND METHODS}

The studies were conducted during a permanent field experiment of the Cherkasy State Agricultural Experimental Station of the National Scientific Center "Institute of Agriculture", NAAS of Ukraine, established in 2010 on the area of 0.75 ha, the number of fields was 5 , the area of seedling plot -30 sq.m., in four repeats.

The experiment was aimed at studying the crop rotation with cereals, grain legumes and technical crops: cereals - up to $60 \%$ (winter wheat-spring barleycorn), grain legumes - up to $20 \%$ (peas), technical crops - up to $20 \%$ (soy).

The soil was podzolic heavily regraded low-humus medium-clay chernozem on carbonate forest layer. The humus content in the arable layer was 2.76-3.22\% according to I.V. Turin, the amount of absorbed alkali - 24.5-28.1 mg-eq. per $100 \mathrm{~g}$ of soil, the hydrolytic acidity - 1.99-2.19 mg-eq./100 g of soil, $\mathrm{pH}$ of the salt extract $-6.0-7.1$. The degree of saturation with alkali was $92.8-93.3 \%$, the content of mobile forms of phosphorus (according to Truog) $9.0 \mathrm{mg}$ per $100 \mathrm{~g}$ of soil, exchange potassium (according to Brovkina) - $12 \mathrm{mg}$ per $100 \mathrm{~g}$ of soil.

The system of soil tillage in the crop rotation: surface tillage with diskers, subsurface tillage for the depth of ploughing and ploughing.

Two fertilization systems were studied in the experiment. The first one - intense fertilization system (control variant) - envisaged the following doses of fertilizers: peas $-\mathrm{N}_{30} \mathrm{P}_{50} \mathrm{~K}_{50}$; winter wheat $-\mathrm{N}_{30} \mathrm{P}_{90} \mathrm{~K}_{90}$ $+\mathrm{N}_{50}+\mathrm{N}_{40}$; soy $-\mathrm{N}_{20} \mathrm{P}_{60} \mathrm{~K}_{60}+\mathrm{N}_{40}$; corn $-\mathrm{N}_{20} \mathrm{P}_{90} \mathrm{~K}_{90}+$ $\mathrm{N}_{100}$; spring barley $-\mathrm{N}_{20} \mathrm{P}_{80} \mathrm{~K}_{80}$. The second one - organic fertilization system (no mineral fertilizers: using by-products of the predecessor as an organic fertilizer, after treating grain with nitrogen-fixing, phosphorusmobilizing biological preparations, growth regulators, humates and enriching with humates, growth regulators for plants or biopreparations).

The climate in the zone of studies is moderately continental. The average annual air temperature is $+7.9{ }^{\circ} \mathrm{C}$, the average monthly air temperature of the coldest month, January, is $-5.9{ }^{\circ} \mathrm{C}$, in July $+19.8{ }^{\circ} \mathrm{C}$. Spring comes in the third decade of March. The notable specificity of spring is an intense increase in temperature. No-frost period lasts 160-170 days. The sum of active temperatures during the period with the temperature above $+10{ }^{\circ} \mathrm{C}$ is $2,650-2,900{ }^{\circ} \mathrm{C}$. The total duration of the vegetation period is 200-210 days.

Balanced estimates of humus were conducted in accordance to the improved method of estimating humus balance in the projects of internal economic land utilization with the consideration of nitrogen removal with the main crop.

The estimation of the accumulation of carbon monoxide amount in a short crop rotation was performed on the following basis:

- crop capacity in different crop rotations in 20112018;

- yield of by-products, after-harvest residues and roots of crops in crop rotations according to the regression equations, presented for low and high levels of crop capacity, as the dependence of the number of plant residues is not always in proportion to the harvest increase; 
- estimation of the yield of dry matter from the obtained mass;

- estimation of carbon content in the mass of byproducts, stubble and roots calculated into carbon oxide (coefficient 3.7);

- estimation of the amount of humus, which was formed as a reservoir of carbon depending on the level of the input of straw, by-products and mass of root system of plants into soil.

The generalization of materials and estimation of the study results was conducted by the method of disperse analysis and STATISTICA package with the non-parametric statistics.

\section{RESULTS AND DISCUSSION}

Mineral forms of nitrogen in the soil are accumulated due to mineralization of root extracts, plant remains, microbial biomass, humic substances and by-products of decomposition of these organic substrates which, by the degree of availability of organic carbon, form an active pool of newly-formed organic substance, the decomposition of which occurs via activation of heterotrophic soil microorganisms, whose activity is regulated by the fertilization system [8].

The estimation of correlation coefficients demonstrated a direct strong correlation between the weight of the total phytomass and its constituents $(\mathrm{R}=+0.82$ $\left.-0.83 \pm 0.02 \mathrm{R}^{2}=0.67-0.69\right)$, and the correlation with the performance indices by the yield of fodder units was $\mathrm{R}=+0.86 \pm 0.02 \mathrm{R}^{2}=0.74$. At the intense system of fertilization, a high level of correlation dependence $(\mathrm{R}=+>0.75)$ was found between the yield of the main product, the aboveground mass and quality indices of the main product. The correlations between the weight of the total phytomass, its constituents and quality indices of the main product were at the level of $\mathrm{R}=+0.59-0.74 \pm 0.03, \mathrm{R}=0.35-0.55$. The introduction of the organic fertilization system led to determining a direct correlation at the level of linear dependence between the weight of the total phytomass, its constituents and the quality of the main product: $\mathrm{R}=+0.98$ $-0.99 \pm 0.03, \mathrm{R}^{2}=0.96-0.98$.

At the intense fertilization system, the total reserves of $\mathrm{N}$ in the phytomass were $3.38 \mathrm{t} / \mathrm{ha}$ at the amplitude of $0.78 \mathrm{t} / \mathrm{ha}$, and by the median the reserves of $\mathrm{N}$ in the

Table 1. Statistical parameters of nitrogen content in the phytomass structure of a short crop rotation at different fertilization systems in 2011-2018

\begin{tabular}{|c|c|c|c|c|}
\hline \multirow{2}{*}{$\begin{array}{l}\text { Statistical } \\
\text { parameters }\end{array}$} & \multicolumn{4}{|c|}{$\mathrm{N}$, (tons/ha): in } \\
\hline & main products & by-products & roots & total phytomass \\
\hline \multicolumn{5}{|c|}{ The intense system of fertilization (control) } \\
\hline $\begin{array}{l}\text { Average value } \\
\text { Min - minimal value } \\
\text { Max - maximal value } \\
\mathrm{Med}_{{ }_{0.50}} \text { - median } \\
\mathrm{L}_{0.25}-\text { lower typical value } \\
\mathrm{L}_{0.75} \text { - upper typical value } \\
\text { Coefficients: } \\
\quad \text { asymmetry } \\
\quad \text { excess } \\
\end{array}$ & $\begin{array}{c}0.98 \\
0.78 \\
1.11 \\
1.00 \\
0.81 \\
1.11 \\
-0.86 \\
-1.12\end{array}$ & $\begin{array}{l}1.09 \\
0.78 \\
1.60 \\
1.08 \\
0.86 \\
1.14 \\
1.24 \\
2.62\end{array}$ & $\begin{array}{c}1.42 \\
1.18 \\
1.51 \\
1.46 \\
1.38 \\
1.51 \\
-1.99 \\
4.14\end{array}$ & $\begin{array}{c}3.38 \\
2.96 \\
3.74 \\
3.52 \\
3.00 \\
3.68 \\
-0.36 \\
-2.28\end{array}$ \\
\hline \multicolumn{5}{|c|}{ The organic system of fertilization } \\
\hline $\begin{array}{l}\text { Average value } \\
\text { Min - minimal value } \\
\text { Max - maximal value } \\
\text { Med, }{ }_{0.50} \text { - median } \\
\mathrm{L}_{0.25} \text { - lower typical value } \\
\mathrm{L}_{0.75} \text { - upper typical value } \\
\text { Coefficients: } \\
\quad \text { asymmetry } \\
\text { excess }\end{array}$ & $\begin{array}{c}0.83 \\
0.68 \\
1.0 \\
0.80 \\
0.76 \\
0.92 \\
\\
0.39 \\
-0.24\end{array}$ & $\begin{array}{l}0.91 \\
0.84 \\
0.96 \\
0.94 \\
0.86 \\
0.96 \\
-0.49 \\
-2.09\end{array}$ & $\begin{array}{c}1.40 \\
1.33 \\
1.44 \\
1.41 \\
1.41 \\
1.42 \\
-1.32 \\
3.91\end{array}$ & $\begin{array}{c}3.15 \\
2.86 \\
3.41 \\
3.12 \\
3.11 \\
3.28 \\
-0.23 \\
1.15\end{array}$ \\
\hline
\end{tabular}


phytomass exceeded the average value by $0.14 \mathrm{t} / \mathrm{ha}$ at the interval typical value of $0.68 \mathrm{t} / \mathrm{ha}$. The value of $\mathrm{N}$ reserves by the median was closer to the upper typical value $(3.68 \mathrm{t} / \mathrm{ha})$. The variation coefficient was $10 \%$, and the approximation error was within the range of $5 \%$. The content of $\mathrm{N}$ in by-products was $1.09 \mathrm{t} / \mathrm{ha}$ with the amplitude of $0.82 \mathrm{t} / \mathrm{ha}(0.78-1.60 \mathrm{t} / \mathrm{ha})$. By the median ( $\mathrm{Med}_{0.50}$ ), the content of $\mathrm{N}$ was at the level of the average value, and the typified interval was 0.86 $-1.14 \mathrm{t} / \mathrm{ha}$. The variation coefficient for nitrogen content exceeded $20 \%$, and the indices of asymmetry and excess had high positive values, which demonstrated high tempo of $\mathrm{N}$ accumulation in by-products. At the intense fertilization system, the reserves of $\mathrm{N}$ in the roots were $1.42 \mathrm{t} / \mathrm{ha}$ with the interval amplitude of 0.33 $\mathrm{t} / \mathrm{ha}$. The reserves of $\mathrm{N}$ by the median were close to the average value (1.46 t/ha) and the typified amplitude was $0.13 \mathrm{t} / \mathrm{ha}$. The variation coefficient was $8 \%$, and the approximation error was under $4 \%$.

At the organic system of fertilization, the content of $\mathrm{N}$ in the main products was $0.83 \mathrm{t} / \mathrm{ha}$ which was 1.19 times lower compared to the intense fertilization system, and the amplitude of the content of $\mathrm{N}$ was at the level of the intense fertilization system, but the mini- mal value of the content of $\mathrm{N}$ was 1.15 times lower. The content of $\mathrm{N}$ by the median was at the level of $0.80 \mathrm{t} / \mathrm{ha}$ which was 1.25 times lower compared to the intense fertilization system. The typified $\left(\mathrm{L}_{0.75}-\mathrm{L}_{0.25}\right)$ amplitude was narrowed down to $0.16 \mathrm{t} / \mathrm{ha}$, which was 2.06 times lower compared to the intense system of fertilization. The average reserves of $\mathrm{N}$ in the roots were at the level of the intense fertilization system $(1.40 \mathrm{t} / \mathrm{ha})$, and the amplitude ( $\Delta=$ max-min) of the content of $\mathrm{N}$ was narrowed down 3 times due to the increase in the minimal value of the content of $\mathrm{N} 1.13$ times to $1.33 \mathrm{t} / \mathrm{ha}$. The typified amplitude of the values of $\mathrm{N}$ content was narrowed down 33 times and was within the interval of the intense fertilization system. The variation coefficient for $\mathrm{N}$ content in the roots reached the level of $2.23 \%$ which was 3.58 times lower compared to the control fertilization variant (Table 1).

The total reserves of $\mathrm{N}$ at the organic fertilization system were 1.07 times lower compared to the intense fertilization system $(3.15 \mathrm{t} / \mathrm{ha})$ at the absolute interval amplitude of $0.55 \mathrm{t} / \mathrm{ha}$. The reserves of $\mathrm{N}$ by the median were at the average value, but by the absolute value it was 1.13 times lower regarding the control fertilization system. Here the typical interval range of $\mathrm{N}$ reserves

Table 2. Statistical parameters of nitrogen balance of a short crop rotation at the organic fertilization system in 2011-2018

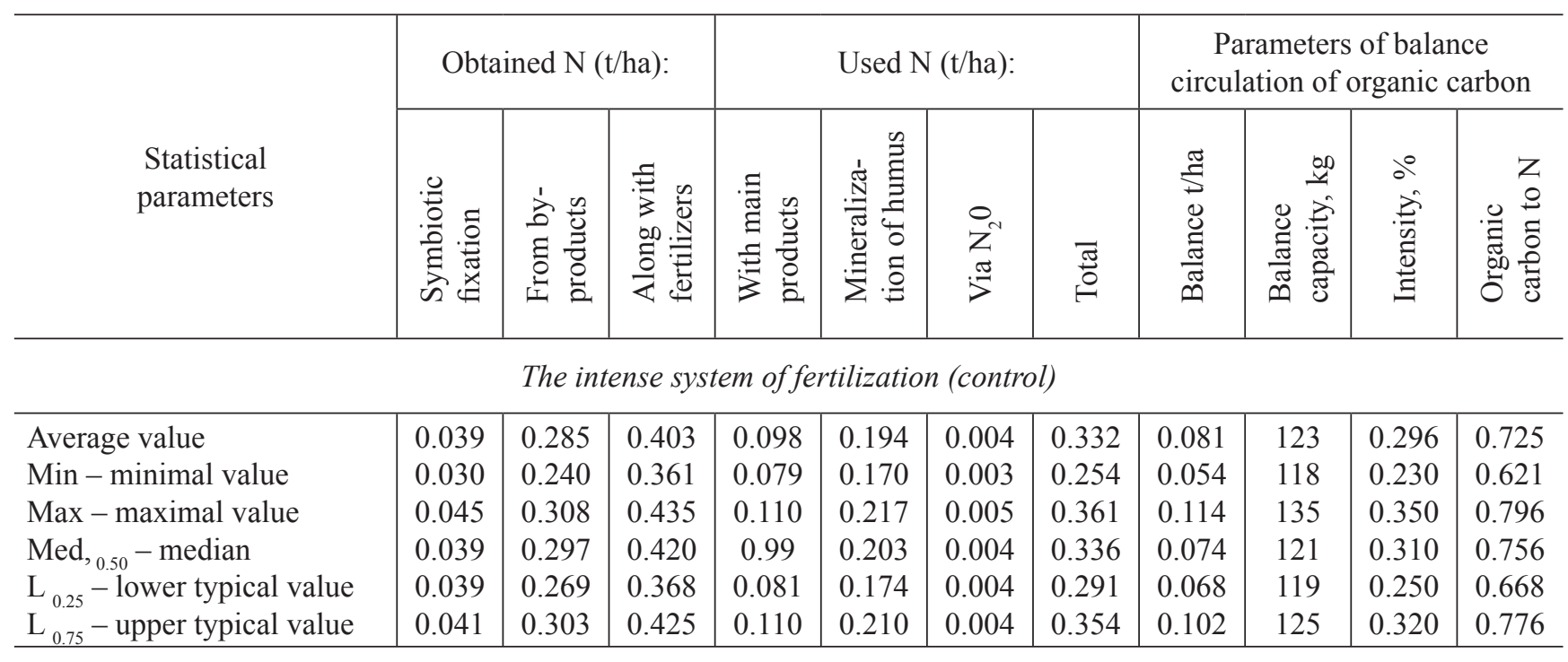

The organic system of fertilization

\begin{tabular}{l|c|c|c|c|c|c|c|c|c|c|c}
\hline Average value & 0.038 & 0.273 & 0.311 & 0.083 & 0.182 & 0.003 & 0.268 & 0.045 & 117 & 0.263 & 0.579 \\
Min - minimal value & 0.037 & 0.237 & 0.274 & 0.068 & 0.159 & 0.002 & 0.230 & 0.024 & 109 & 0.230 & 0.503 \\
Max - maximal value & 0.041 & 0.238 & 0.324 & 0.100 & 0.197 & 0.004 & 0.301 & 0.060 & 123 & 0.310 & 0.624 \\
Med, ${ }_{0.50}$ - median & 0.038 & 0.279 & 0.317 & 0.082 & 0.183 & 0.003 & 0.266 & 0.045 & 118 & 0.250 & 0.582 \\
$\mathrm{~L}_{0.25}$ - lower typical value & 0.037 & 0.237 & 0.310 & 0.076 & 0.182 & 0.002 & 0.260 & 0.030 & 112 & 0.240 & 0.579 \\
$\mathrm{~L}_{0.75}$ - upper typical value & 0.039 & 0.281 & 0.319 & 0.093 & 0.188 & 0.003 & 0.285 & 0.057 & 122 & 0.290 & 0.600 \\
\hline
\end{tabular}


was narrowed down 4 times. The variation coefficient of $\mathrm{N}$ reserves in the crop rotation decreased 1.78 times, and the asymmetry coefficient was negative regarding the 1.13 times lower absolute value of the control fertilization system.

At the intense fertilization system, the intake of $\mathrm{N}$ was $0.403 \mathrm{t} / \mathrm{ha}$ at the amplitude of $0.361-0.435 \mathrm{t} / \mathrm{ha}$ $(\Delta=0.074 \mathrm{t} / \mathrm{ha})$. By the median, the intake of $\mathrm{N}$ was $0.420 \mathrm{t} / \mathrm{ha}$ at the typified amplitude of $0.57 \mathrm{t} / \mathrm{ha}$. The value of $\mathrm{N}$ intake by the median was closer to the upper typical value $\left(\mathrm{L}_{0.75}=0.425 \mathrm{t} / \mathrm{ha}\right)$, which demonstrated the increase in the amount of $\mathrm{N}$ in the crop rotation. The variation coefficient was $7.32 \%$, and the approximation error was under $4 \%$.

At the organic system of fertilization, the average intake of $\mathrm{N}$ was $0.311 \mathrm{t} / \mathrm{ha}$, which was 1.3 times lower, and the amplitude of the intake was narrowed down to $0.05 \mathrm{t} / \mathrm{ha}$, which was 12 times lower compared to the intense fertilization system.

The normalized amplitude of the intake was narrowed down to the interval range of $0.310-0.319 \mathrm{t} / \mathrm{ha}$ which was 6.3 times lower by the amplitude compared to the intense fertilization system. The variation coefficient for $\mathrm{N}$ intake did not exceed $6 \%$ and the approximation error was $2.5-3.0 \%$. At the intense fertilization system, the removal of $\mathrm{N}$ with the main products was $0.098 \mathrm{t} / \mathrm{ha}$ at the internal amplitude of $0.031 \mathrm{t} / \mathrm{ha}$. By the median, the removal of nitrogen was close to the average value and the typified interval coincided with the interval amplitude by the variation coefficient of $13.5 \%$. The coefficients of asymmetry and excess were negative with the considerable deviation of the latter from the distribution center (Table 2).

At the organic system of fertilization, the average removal of $\mathrm{N}$ was 1.18 lower $(0.083 \mathrm{t} / \mathrm{ha})$ regarding the intense system of fertilization at the interval amplitude from $0.068 \mathrm{t} / \mathrm{ha}$ to $0.100 \mathrm{t} / \mathrm{ha}$. The value of $\mathrm{N}$ removal by the median was 1.2 times lower compared to the 1.78-fold narrowed down typical interval amplitude (0.076-0.093 t/ha) regarding the control fertilization variant. The variation coefficient was $13 \%$, and the coefficients of asymmetry and excess had insignificant deviation from the distribution center. The removal of $\mathrm{N}$ due to humus mineralization at the intense fertilization system was $0.194 \mathrm{t} / \mathrm{ha}$ on average at the amplitude of $0.047 \mathrm{t} / \mathrm{ha}(0.0170-0.217 \mathrm{t} / \mathrm{ha}$.) The value of $\mathrm{N}$ removal by the median was at the level of $0.203 \mathrm{t} / \mathrm{ha}$, which was $4.5 \%$ higher than the average value that was closer to the upper typical value of the removal (0.210 t/ha).
On average, the removal of $\mathrm{N}$ due to humus mineralization was 1.07 times lower regarding the intense system of fertilization at the absolute value of $0.182 \mathrm{t} /$ ha. The amplitude of $\mathrm{N}$ removal values was 1.24 times lower, amounting to $0.159-0.197 \mathrm{t} / \mathrm{ha}$. The value of $\mathrm{N}$ removal by the median was 1.1 times lower and was getting closer to the average by the absolute value. The typical interval of $\mathrm{N}$ removal values was 6 times lower compared to the variation coefficient of $6.26 \%$ which was 1.61-1.88 times lower compared to the intense system of fertilization. The asymmetry coefficient was negative, and it was 5 times higher which demonstrated intense retention of $\mathrm{N}$ removal due to humus mineralization. The removal of $\mathrm{N}$ due to humus mineralization at the intense fertilization system was $0.332 \mathrm{t} / \mathrm{ha}$ at the amplitude of $0.254 \mathrm{t} / \mathrm{ha}$ to $0.361 \mathrm{t} / \mathrm{ha}$ or $0.11 \mathrm{t} / \mathrm{ha}$. The value of the total removal by the median was at the level of the average value of $0.336 \mathrm{t} / \mathrm{ha}$ at the normalized interval of values which was in the range of amplitude of $0.291-0.354 \mathrm{t} / \mathrm{ha}$. The variation coefficient of the total removal of $\mathrm{N}$ was $12.3 \%$ and the coefficients of asymmetry and excess had negative values and were getting to the center of the parameter distribution.

At the intense fertilization system, the balance of nitrogen was $+0.081 \mathrm{t} / \mathrm{ha}$ at the amplitude from +0.054 to $+0.117 \mathrm{t} / \mathrm{ha}$. By the median the balance of $\mathrm{N}$ was at the level of $+0.074 \mathrm{t} / \mathrm{ha}$ and the typified amplitude of the balance of $\mathrm{N}$ was $0.068-0.102 \mathrm{t} / \mathrm{ha}$. The value of the balance of $\mathrm{N}$ by the median was getting closer to the lower typical value. The variation coefficient was $25.4 \%$, and the coefficients of asymmetry and excess had insignificant deviation from the distribution center.

At the organic system of fertilization, the balance of $\mathrm{N}$ in the crop rotation was positive, but 1.8 times lower by the absolute value regarding the intense fertilization system $-0.045 \mathrm{t} / \mathrm{ha}$. The absolute amplitude of the balance of $\mathrm{N}$ was 1.67 times lower and the interval values were also 2.25 and 1.9 times lower. The balance of $\mathrm{N}$ by the median was at the level of $+0.048 \mathrm{t} / \mathrm{ha}$ which was 1.54 times lower compared to the intense fertilization system. The typified parameters of the balance fluctuated within the range of $\Delta=0.030-0.057 \mathrm{t} / \mathrm{ha}$ which were 2.27 and 1.79 times lower. The variation coefficient increased 1.21 times and the values of asymmetry and excess of the distribution sampling were negative (left asymmetry), by the asymmetry they were getting closer to the distribution center, and it was considerable by the excess of deviation from the center by left asymmetry. 


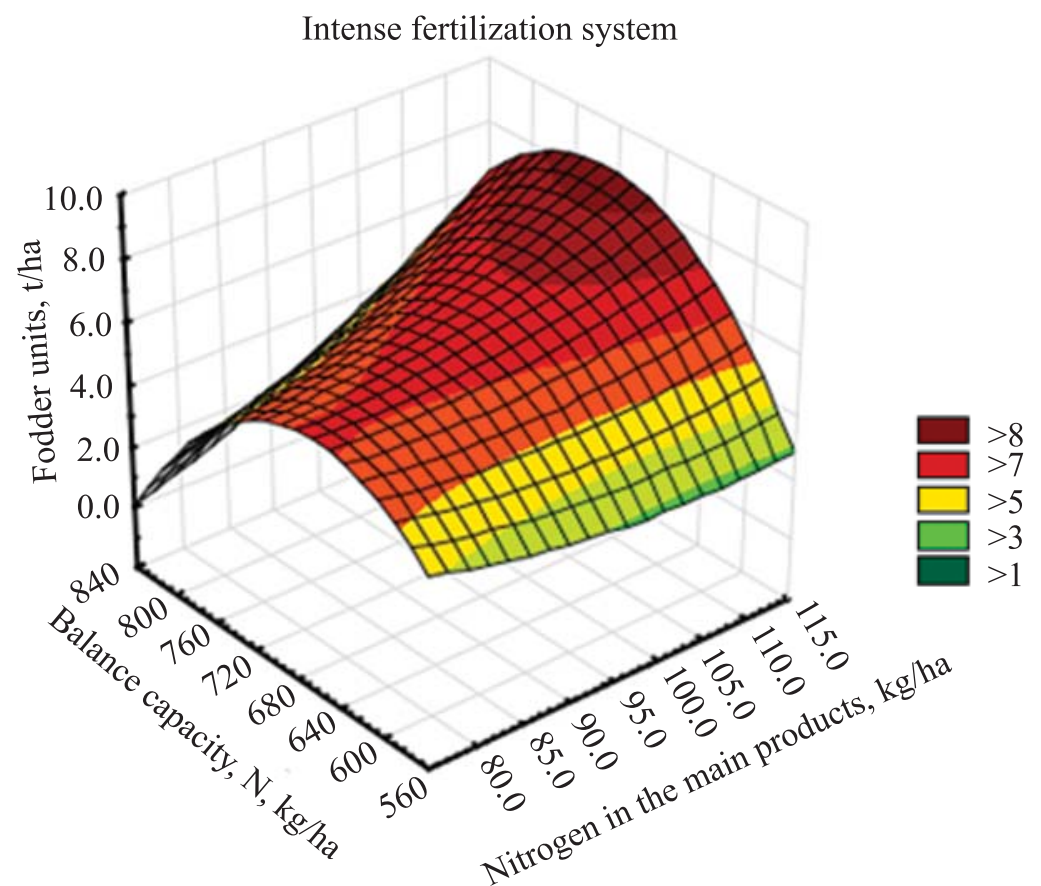

Fodder units, $\mathrm{t} / \mathrm{ha}=-33.07-0.68 * \mathrm{x}+0.20 * \mathrm{y}+0.0014 * \mathrm{x}^{2}+0.0007 * \mathrm{x} * \mathrm{y}-0.0002 * \mathrm{y}^{2}$

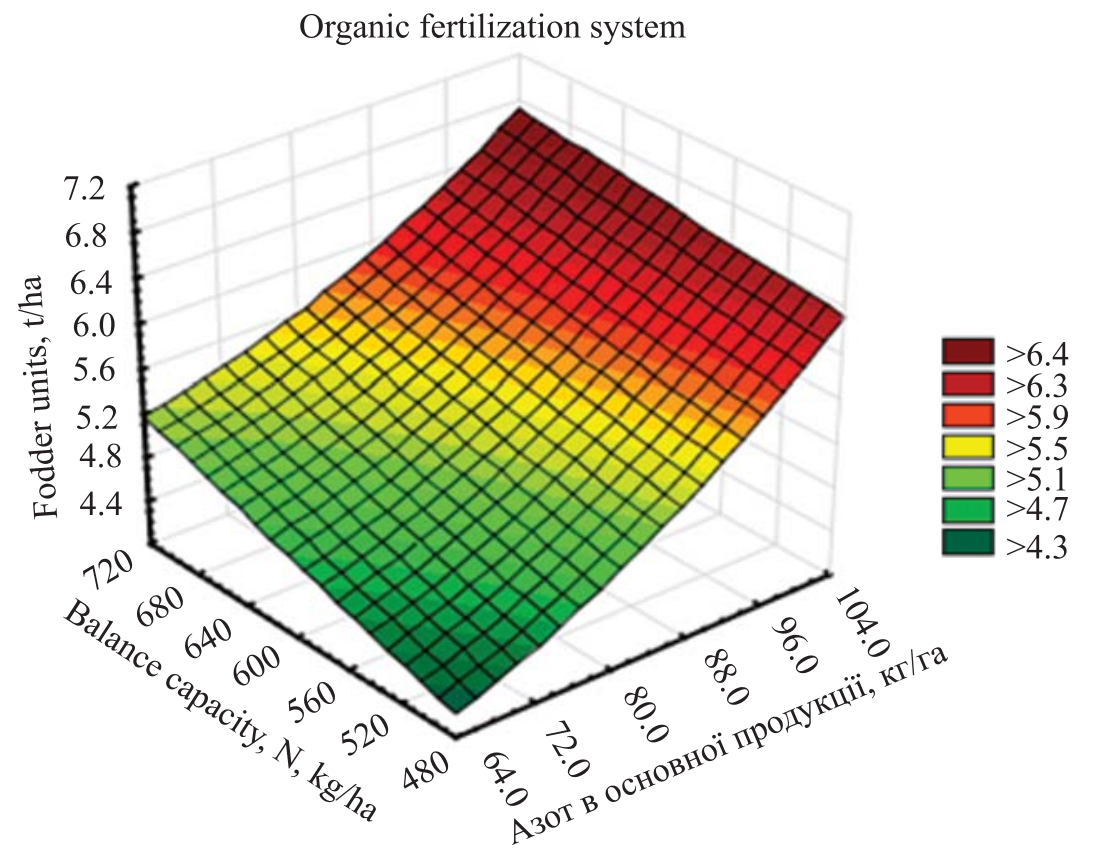

Fodder units, $\mathrm{t} / \mathrm{ha}=1.09-0.012 * \mathrm{x}+0.007 * \mathrm{y}+0.001 * \mathrm{x}^{2}-5.9128 \mathrm{E}-5 * \mathrm{x} * \mathrm{y}+1.0279 \mathrm{E}-6 * \mathrm{y}^{2}$

Fig. 1. The capacities of balance, the removal of nitrogen by the main products and the performance of a short crop rotation with grain and intertilled crops depending on the fertilization system in 2011-2018

The capacity of nitrogen balance at the intense fertilization system for the crop rotation was $0.725 \mathrm{t} / \mathrm{ha}$ of nitrogen, and its amplitude fluctuated from 0.621 to $0.796 \mathrm{t} / \mathrm{ha}$ with the amplitude of $0.175 \mathrm{t} / \mathrm{ha} \mathrm{N}$. The value of the nitrogen balance capacity by the median was $0.756 \mathrm{t} / \mathrm{ha}$ with the typical amplitude from 0.668 to $0.775 \mathrm{t} / \mathrm{ha}(\Delta=+0.107 \mathrm{t} / \mathrm{ha})$.
The value of nitrogen balance capacity was getting closer to the upper typical value $\left(\mathrm{L}_{0.75}=0.775 \mathrm{t} / \mathrm{ha}\right)$, which demonstrated the increase in the balance capacity. The variation coefficient of the balance capacity was $9.22 \%$ and the coefficients of asymmetry and excess had negative values and a considerable deviation from the center of the sampling distribution. 


\section{DEMYDENKO et al.}

At the organic system of fertilization, the capacity of $\mathrm{N}$ balance on average for the crop rotation decreased 1.25 times regarding the intense system of fertilization, reaching $0.579 \mathrm{t} / \mathrm{ha}$. The amplitude fluctuated from 0.503 to $0.624 \mathrm{t} / \mathrm{ha}(+0.121 \mathrm{t} / \mathrm{ha})$, which was 1.5 times lower compared to the control variant of fertilization. The value of $\mathrm{N}$ balance capacity by the median regarding the intense system of fertilization decreased 1.3 times and was getting closer to the average value (0.582 t/ha). The typical interval of values of $\mathrm{N}$ balance capacity fluctuated within a smaller interval of values $(0.579-0.600 \mathrm{t} / \mathrm{ha})$ and the typified amplitude regarding the intense system of fertilization was 5.1 times lower. The variation coefficient was $6.4 \%$ which was 1.44 times lower regarding the intense system of fertilization. The asymmetry coefficient was negative which demonstrated the stability of forming the capacity of $\mathrm{N}$ balance under organic fertilization system.

The yield of fodder units in a short crop rotation with grain and intertilled crops in 2011-2018 from the capacity of balance and nitrogen content in the main products demonstrated that at the intense system of fertilization the dependence was of parabolic- plane nature, and the maximal performance $(>8.0 \mathrm{t} /$ ha) was noted for the capacity of nitrogen balance in the interval range of 640-750 kg, which ensured nitrogen accumulation in the main products at the level of $100-115 \mathrm{~kg} / \mathrm{ha}$. At the organic system of fertilization, the dependence of the increase in the yield of fodder units in a short crop rotation with grain and intertilled crops was of linear plane nature which was related to the 1.18-1.25-fold decrease in the performance regarding the intense system of fertilization (Fig. 1).

Supporting a specific level of soil provision with potentially mineralized carbon is a relevant prerequisite of including mineral nitrogen of soil into subsurface immobilization-remineralization circulation which is extremely important both for intense and organic fertilization systems.

Here the dynamics of mineralization-immobilization of nitrogen in soil depends on the ability to mineralize organic substrates and conditions, controlling remineralization of previously immobilized nitrogen, rather than on the total content of carbon and nitrogen in fresh organic substance [19].

Table 3. Statistical parameters of organic carbon balance of a short crop rotation at the organic fertilization system in 2011-2018

\begin{tabular}{|c|c|c|c|c|c|c|c|c|c|c|c|}
\hline \multirow[b]{2}{*}{$\begin{array}{l}\text { Statistical } \\
\text { parameters }\end{array}$} & \multicolumn{3}{|c|}{$\begin{array}{l}\text { Obtained organic } \\
\text { carbon, } \mathrm{t} / \mathrm{ha}\end{array}$} & \multicolumn{4}{|c|}{ Lost organic carbon, $\mathrm{t} / \mathrm{ha}$} & \multicolumn{4}{|c|}{$\begin{array}{l}\text { Parameters of balance } \\
\text { circulation organic carbon }\end{array}$} \\
\hline & 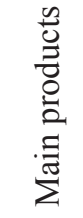 & 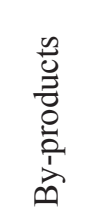 & $\begin{array}{l}n \\
0 \\
0\end{array}$ & 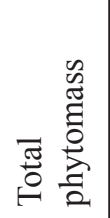 & 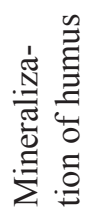 & 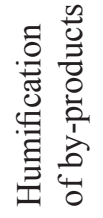 & $\stackrel{\pi}{0}$ & 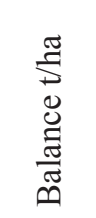 & 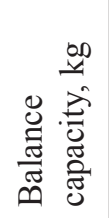 & 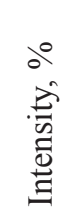 & 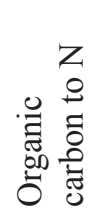 \\
\hline \multicolumn{12}{|c|}{ The intense system of fertilization (control) } \\
\hline Average value & 1.92 & 5.76 & 4.56 & 12.2 & 1.78 & 2.32 & 4.11 & 0.57 & 4.11 & 130 & 24.0 \\
\hline Min - minimal value & 1.56 & 5.11 & 3.61 & 10.3 & 1.51 & 2.24 & 3.75 & 0.38 & 3.76 & 121 & 22.0 \\
\hline Max - maximal value & 2.21 & 6.31 & 4.91 & 13.4 & 1.92 & 2.56 & 4.48 & 0.99 & 10.9 & 151 & 27.0 \\
\hline Med, ${ }_{0.50}-$ median & 1.95 & 5.81 & 4.71 & 12.5 & 1.87 & 2.28 & 4.15 & 0.46 & 4.16 & 126 & 24.0 \\
\hline $\mathrm{L}_{0.25}-$ lower typical value & 1.61 & 5.21 & 4.51 & 11.3 & 1.66 & 2.24 & 3.91 & 0.41 & 3.91 & 126 & 22.0 \\
\hline $\mathrm{L}_{0.75}^{0.25}-$ upper typical value & 2.21 & 6.21 & 4.82 & 13.2 & 1.88 & 2.32 & 4.20 & 0.76 & 4.28 & 136 & 24.0 \\
\hline \multicolumn{12}{|c|}{ The organic system of fertilization } \\
\hline Average value & 1.61 & 5.27 & 4.45 & 11.3 & 1.69 & 2.22 & 4.18 & 0.54 & 4.81 & 135 & 28.0 \\
\hline Min - minimal value & 1.34 & 5.00 & 4.21 & 10.6 & 1.58 & 2.12 & 3.71 & 0.48 & 3.72 & 128 & 26.0 \\
\hline Max - maximal value & 1.91 & 5.81 & 4.71 & 12.4 & 2.01 & 2.55 & 4.56 & 0.56 & 10.7 & 149 & 30.0 \\
\hline Med, ${ }_{0.50}-$ median & 1.60 & 5.11 & 4.41 & 11.1 & 1.62 & 2.16 & 3.78 & 0.54 & 3.79 & 133 & 28.0 \\
\hline $\mathrm{L}_{0.25}-$ lower typical value & 1.51 & 5.11 & 4.41 & 11.0 & 1.58 & 2.14 & 3.72 & 0.52 & 3.78 & 131 & 27.0 \\
\hline $\mathrm{L}_{0.75}^{0.23}$ - upper typical value & 1.81 & 5.61 & 4.61 & 12.0 & 1.74 & 2.22 & 3.96 & 0.56 & 3.96 & 135 & 29.0 \\
\hline
\end{tabular}


At the intense fertilization system, the ratio of the content of organic carbon in the components of total phytomass was as follows: carbon of the main product: by-product : root mass $=1$ to 3.0 to 2.42 , which was $-15.6,46.5,37.9 \%$ in percentage ratio. The average content of organic carbon in the main products was $1.92 \mathrm{t} / \mathrm{ha}$ at the amplitude range from 1.52 to $2.21 \mathrm{t} / \mathrm{ha}$ $(0.69 \mathrm{t} / \mathrm{ha})$. The variation coefficient for organic carbon in the main product was $14.1 \%$ and the coefficients of asymmetry and excess had negative values.

The variation coefficient of organic carbon in the main product was 1.18 -fold lower, reaching the values of $11.9 \%$ and the coefficients of asymmetry and excess fluctuated inconsiderably regarding the distribution center which demonstrated the stabilization of the emission of organic carbon in the main products during the period of investigating different systems of fertilization for chernozem.

The reserves of organic carbon in by-products at the intense fertilization system reached $5.76 \mathrm{t} / \mathrm{ha}$ with the amplitude from 5.11 to $6.31 \mathrm{t} / \mathrm{ha}$. The typified quarterly amplitude was $1 \mathrm{t} / \mathrm{ha}(\Delta=5.21-6.21 \mathrm{t} / \mathrm{ha})$. The variation coefficient was $10 \%$ lower and the coefficients of asymmetry and excess were negative, which demonstrated left asymmetry and the dynamic nature of carbon accumulation in by-products.

The accumulation of organic carbon in the root system at the intense fertilization system was at the level of $4.56 \mathrm{t} / \mathrm{ha}$ and the amplitude was $1.3 \mathrm{t} / \mathrm{ha}$ (3.61$-4.91 \mathrm{t} / \mathrm{ha}$ ). By the median, the reserve of carbon in the roots was closer to the typical value of the reserves $\left(\mathrm{L}_{0.75}=4.92 \mathrm{t} / \mathrm{ha}\right)$ at the typical interval of $\Delta=0.31 \mathrm{t} / \mathrm{ha}$. The variation coefficient was under $10 \%$, and the coefficients of asymmetry and excess had high values, which demonstrated the dynamic change in carbon reserves in the roots (Table 3).

The systematic application of the organic system of fertilization led to the 1.09-fold decrease in the reserves of organic carbon in the by-products regarding the intense system of fertilization, and the amplitude was narrowed down 1.48 times and fluctuated from 5.00 to $5.81 \mathrm{t} / \mathrm{ha}(+0.81 \mathrm{t} / \mathrm{ha})$. By the median, the reserves of carbon in by-products were mostly getting closer to the minimal typical value $\left(\mathrm{L}_{0.25}=5.00 \mathrm{t} / \mathrm{ha}\right)$, and the typical amplitude of the index was twice lower. The variation coefficient decreased 1.45 times and the coefficients of asymmetry and excess were positive and had right asymmetry, which demonstrated the stabilization of directing the processes of carbon accumulation in the by-products at the organic system of fertilization.
The organic fertilization system led to the decrease in carbon reserves in the phytomass down to $11.3 \mathrm{t} / \mathrm{ha}$ which was 1.09 times lower compared to the intense system of fertilization.

Narrowing down the amplitude of organic carbon reserves 1.72 times was revealed due to the 1.08 -fold decrease in the reserves by the maximal value during the investigation years. Carbon reserves by the median were getting closer to the reserve values at average measurements, but regarding the control system of fertilization the reserves of carbon decreased 1.13 times, and the typical amplitude of the reserves -1.9 times, the variation coefficient was found to be under $5 \%$ which was 1.78 times lower compared to the intense fertilization system.

While applying the organic fertilization system, the humification process for organic carbon of plant remains and by-products by average and median values was slowed down 1.05-1.06 times and the typified amplitude of organic carbon humification regarding the amplitude decreased 5.37 times. The variation coefficient amounted to $6.68 \%$, and the coefficients of asymmetry and excess were positive, similar to the intense fertilization system, which characterized high intensity of the direction of carbon humification of plant residues, but at a lower quantitative level due to decreased intake of organic mass prior to humification.

At the intense system of fertilization, the average capacity of organic carbon balance was $4.11 \mathrm{t} / \mathrm{ha}$ and by the median $-4.16 \mathrm{t} / \mathrm{ha}$. The normative amplitude of balance capacity was $0.37 \mathrm{t} / \mathrm{ha}$ which was 19.3 times lower than the amplitude. The organic system of fertilization led to the 1.08-1.1-fold decrease in balance capacity by the average and median values regarding the intense system of fertilization. The balance capacity by the median was getting closer to the minimal typical value $\left(\mathrm{L}_{0.25}=3.79 \mathrm{t} / \mathrm{ha}\right)$, and the normalized amplitude regarding the intense system of fertilization decreased 2.06 times. The variation coefficient was at the level of $5 \%$, and the coefficients of asymmetry and excess were positive at high absolute values.

Carbon balance at the intense fertilization system was positive $(\mathrm{B}=+0.57 \mathrm{t} / \mathrm{ha})$, and the average value coincided with the balance value by the median. The amplitude of carbon balance was +0.61 t/ha and exceeded the normalized value 1.74 times. The variation coefficient of carbon balance was $40 \%$ and the excess coefficient had a positive value and right asymmetry.

Despite of the detected regularity, the intensity of organic carbon balance was at a high level, regard- 
less of the fertilization system: the intense system of fertilization $-126-136 \%$, and the organic system of fertilization $-131-135 \%$. The variation coefficient of balance intensity at the organic system of fertilization did not exceed $5 \%$, and the coefficient of asymmetry of the sampling distribution was positive and had right asymmetry in the distribution of the sampling of values which demonstrated a stable increase in balance intensity towards activation.

The decomposition of fresh organic substance of the active pool occurred via the priority use of organic carbon by heterotrophic microorganisms which performed a structure-forming and energy-supplying function in metabolism. Microorganisms received the required amount of nitrogen from the organic substrate in the form of aminoacids or while consuming mineral forms of nitrogen from soil. Here the biomass of heterotrophic microflora had a narrower ratio of $\mathrm{C}: \mathrm{N}$ compared to fresh organic substrate, consumed by them. It is difficult to determine in which way the conditions for capability to mineralization-immobilization of nitrogen of the organic substance are made up at different fertilization systems, and which conditions regulate the re-mineralization of previously immobilized nitrogen [25-30].

The statistical estimation of the ratio between organic carbon and $\mathrm{N}$ in the agrocenosis of a short crop rotation demonstrated that at the intense fertilization system, the average and median value of the ratio was 24 to 1 , and the amplitude and normative amplitude was 22-27 to 1 and $22-24$ to 1 . The ratio of organic carbon to $\mathrm{N}$ by the median was getting closer to the upper typical value. The variation coefficient $\mathrm{C}$ to $\mathrm{N}$ in a crop rotation was $7.19 \%$ and the asymmetry coefficient was positive and had right asymmetry with a considerable deviation from the center of sampling distribution.

At the organic system of fertilization, the ratio of organic carbon to $\mathrm{N}$ in the agrocenosis of a short crop rotation by the average and median value reached 28 to 1 , and the amplitude and typified interval of values was $26-30$ to 1 and $27-29$ to 1 . The typified interval amplitude of the $\mathrm{C}$ to $\mathrm{N}$ ratio was narrower and the value of the ratio, which corresponded to the minimal and maximal typical state, were 1.22-fold higher compared to the intense fertilization system. The variation coefficient did not exceed $5 \%$ and the asymmetry coefficient was positive.

The factor analysis allowed tracing the stability of correlations between the investigated parameters as well as between parameters and general factors, which carried the main diagnostic information about the processes in agrocenoses. The general model of nutrition demonstrated a strong reverse correlation between the main factor $\left(F_{1}\right)$ - the yield of fodder units and the main products and the capacity of nitrogen balance $\left(\mathrm{R}=-0.90-0.96 \pm 0.02 ; \mathrm{R}^{2}=0.81-0.92\right)$, and the capacity of organic carbon correlated with factor $\mathrm{F}_{2}$ at the level of a strong direct correlation $(\mathrm{R}=+0.96 \pm 0.02$; $\left.\mathrm{R}^{2}=0.92\right) .70 .0 \%$ of total dispersion of factors accrued to factor $\mathrm{F}_{1}$, and $\mathrm{F}_{2}-16.0 \%$. Two factors combine $86.0 \%$ of dispersion. Determining the factor burden at the intense and organic fertilization systems by the abovementioned parameters was similar to the general model, but at the intense fertilization system, the distribution of total dispersion between factors was wider: $\mathrm{F}_{1}=67.0 \%, \mathrm{~F}_{2}=24.0 \%$, and two factors combined $91.0 \%$ of the total dispersion. At the organic system of fertilization, the distribution of dispersion corresponded to the general model of fertilization. The factor analysis allowed revealing the determining parameters of nutrition models, which were as follows: the yield of fodder units and the main products, the capacity of nitrogen balance and organic carbon.

The general model of dependence of the yield of the main product on the content of organic carbon in the main and by-products, roots, non-commodity total phytomass demonstrated the presence of strong direct correlations $\left(\mathrm{R}=+0.75-0.84 \pm 0.02 ; \mathrm{R}^{2}=0.56-0.71\right)$.

The relationship between the yield of main products and fodder units and the capacity balance of carbon was at the level of direct correlation $(\mathrm{R}=+0.65 \pm 0.03$; $\left.\mathrm{R}^{2}=0.43\right)$. Per one unit of the yield of the main product, there were 0.37 units of organic carbon in the main product, 0.56 units of carbon in the by-product, 0.28 units of carbon in the roots and 0.86 units of the total non-commodity phytomass. At the intense fertilization system, there was a preserved close direct correlation between the yield of the main products and the content of organic carbon in structural components of the phytomass $\left(\mathrm{R}=+0.79-0.84 \pm 0.02 ; \mathrm{R}^{2}=0.62-0.71\right)$.

Per one unit of the yield of fodder units, there were 0.27 units of carbon of the main products, 0.42 units of carbon in the by-products, 0.23 units of carbon in the roots, 0.65 units of carbon of the total non-commodity phytomass, and per one unit of the increase in the yield of fodder units, there was a decrease in the capacity balance of carbon by 1.51 units in the agrocenosis.

Under conditions of the intense system of fertilization, the relationships between the yield of fodder units and carbon in the structure of the total phytomass were 


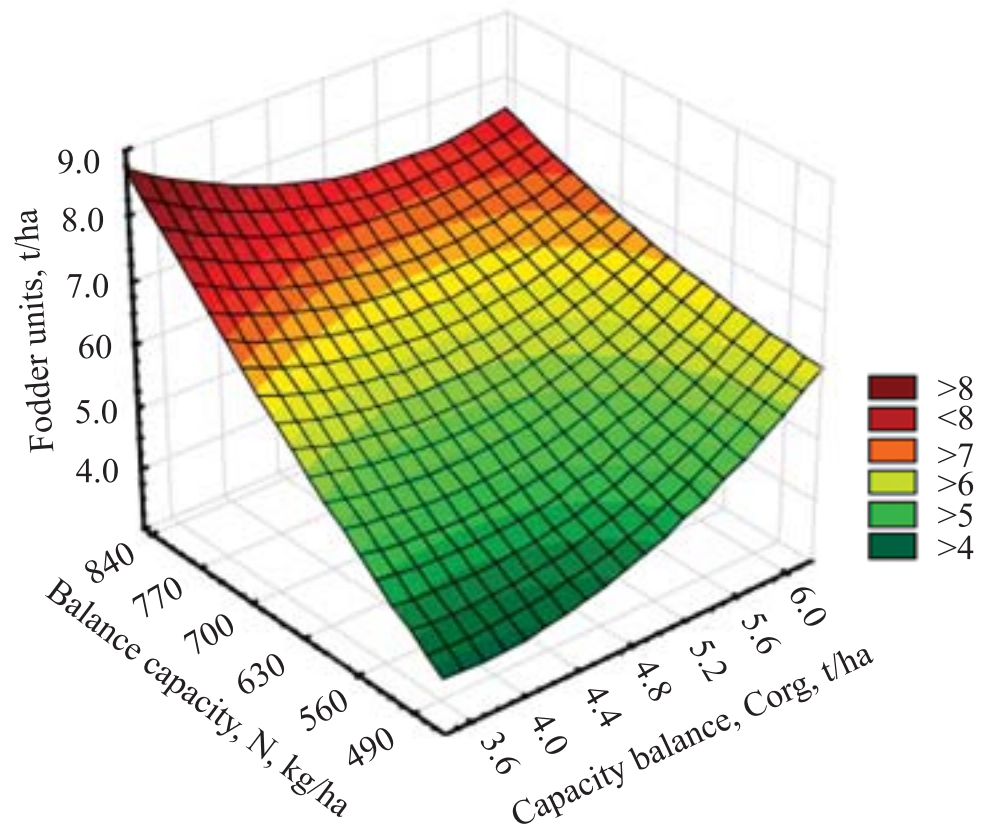

Fodder units, $\mathrm{t} / \mathrm{ha}=-30.35-1.05 * \mathrm{x}+0.02 * \mathrm{y}+0.34 * \mathrm{x}^{2}-0.003 * \mathrm{x} * \mathrm{y}+5.8 \mathrm{E}-6 * \mathrm{y}^{2}$

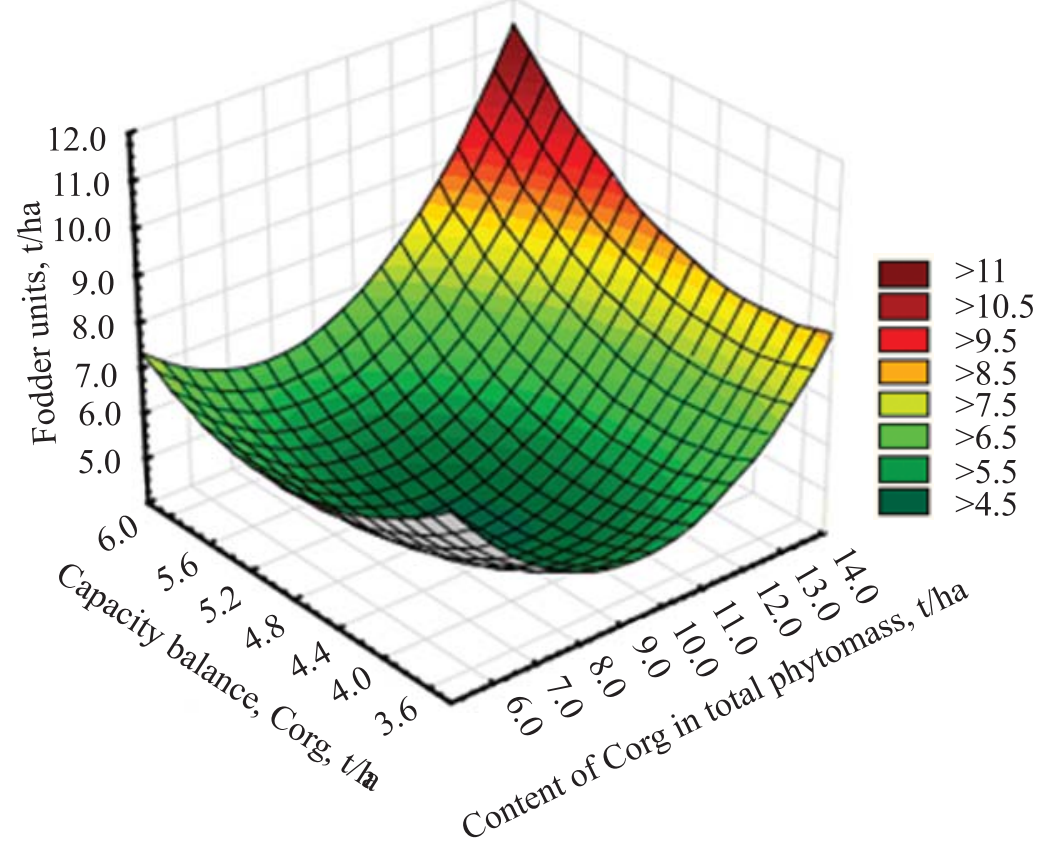

Fodder units, $\mathrm{t} / \mathrm{ha}=36.1-3.21 * \mathrm{x}-7.63 * \mathrm{y}+0.15 * \mathrm{x}^{2}+0.15 * \mathrm{x} * \mathrm{y}+0.69 * \mathrm{y}^{2}$

Fig. 2. The dependence of the performance of a short crop rotation with grain and intertilled crops on the capacity balance of $\mathrm{N}$ and organic carbon

at the level of a strong direct correlation $\mathrm{R}=+0.81-$ $0.85 \pm 0.02 ; \mathrm{R}^{2}=0.65-0.72$, and per one unit of the increase in the yield of fodder units there was a 1.72-fold increase in the capacity balance of carbon, amounting to 2.59 units of organic carbon.

Direct and strong correlations were kept between the yield of fodder units and the content of organic carbon in the structural components of the total phytomass at the organic fertilization system: with organic carbon in the main product and the root mass: $\mathrm{R}=+0.86$ $-0.88 \pm 0.02 ; \mathrm{R}^{2}=0.74-0.77$, and with the content of carbon in the by-products and non-commodity total phytomass the relationship with the yield of fodder units was at the level of direct average correlation $\mathrm{R}=+0.58-0.65 \pm 0.02, \mathrm{R}^{2}=0.34-0.43$; and the increase in the yield of fodder units was accompanied 
with the reverse correlation of the medium level: $\mathrm{R}=-0.64 \pm 0.03 ; \mathrm{R}^{2}=0.41$. There were $0.28-0.29$ units of carbon of the main product per one unit of the yield of fodder units, regardless of the fertilization system. Carbon of the by-products was spent 1.28-1.51 times, carbon of the roots -1.44 , total non-commodity phytomass $-1.28-1.94$ times less compared to the general model and the model of intense system of fertilization. The increase in the yield of one fodder unit was accompanied with the 1.32-fold decrease in the capacity balance of carbon regarding the intense system of fertilization.

The capacity balance of nitrogen is a determining factor in the formation of high performance of agrocenosis, as it is subject to the capacity balance of carbon, the increase in which to the critical limit starts inhibiting the performance, which is related to the increase in the share of carbon capacity, which is accumulated by humus. At the intense system of fertilization the yield of fodder units up to 8.0-8.5 t/ha was accompanied with the increase in the capacity balance up to 4.0 $4.6 \mathrm{t} / \mathrm{ha}$, whereas at the organic system of fertilization, the yield of fodder units decreased to 7.5-8.0 $\mathrm{t} / \mathrm{ha}$ which was accompanied with the increase in the capacity balance for carbon in which the share of organic carbon of humus increased regarding the intense system of fertilization, Fig. 2.

\section{CONCLUSIONS}

Direct and strong correlations were revealed between the yield of fodder units and the content of organic carbon in the structural components of the total phytomass at the organic fertilization system: with carbon in the main products and root mass $-\mathrm{R}=+0.86-0.88 \pm 0.02$; $\mathrm{R}^{2}=0.74-0.77$, and with the content of carbon in byproducts and non-commodity total phytomass the relationship with the yield of fodder units was on the level of direct average correlation $\mathrm{R}=+0.58-0.65 \pm 0.02$; $\mathrm{R}^{2}=0.34-0.43$. The increase in the yield of fodder units was accompanied with the 1.32 -fold decrease in the capacity balance of carbon regarding the intense system of fertilization.

At the organic system of fertilization, the ratio of organic carbon and nitrogen in the agrocenosis of a short crop rotation was the most optimal: 30 to 1 , which was the most profitable for humification of by-products and the decrease in the intensity of humus mineralization, which allowed reaching the positive values of the balance of organic balance at lower components of the balance items and a high level of balance intensity. Balance capacity was a restrictive factor in the circulation of carbon at the organic system of fertilization, which considerably conceded to the balance capacity of carbon at the intense fertilization system.

The performance of a short crop rotation with grain and intertilled crops was defined by the balance capacity of nitrogen and organic carbon and the content of these biogenic elements both in the main and total phytomass of crops in the rotation. At the intense fertilization system, the relationship between the yield of fodder units, the mass of the main products and the balance capacity of nitrogen, organic carbon and the content of these elements in the total phytomass had a parabolic character, and at the organic system - linearplane nature. The capacity of circulation nitrogen and organic carbon at the organic fertilization system and reserves of these biogenic elements in the total phytomass and the main products was 1.15-1.25 times lower compared to the intense system of fertilization, which was related to the 1.25-1.3-fold lower yield of the main products.

This article does not relate to any studies using humans and animals as investigation subjects.

Conflict of interests. The authors deny any conflict of interests.

Financing. This study did not receive any specific grant from the financing institutions in state, commercial or non-commercial sectors.

\section{Азот-вуглецевий обіг в агроценозах за різних систем удобрення}

О. В. Демиденко ${ }^{1}$, В. А. Величко ${ }^{2}$

\footnotetext{
${ }^{1}$ Черкаська державна сільськогосподарська дослідна станція ННЦ «Інститут землеробства НААН України» Вул. Докучаєва, 13, с. Холоднянське, Смілянський р-н, Черкаська обл., Україна

${ }^{2}$ ННЦ «Інститут грунтознавства і агрохімії ім.О.Н.Соколовського НААН» м. Харків, вул. Чайковська, 2,Україна, 61024
}

e-mail: smilachiapv@ukr.net, agrovisnyk@ukr.net

Мета. Провести порівняльну оцінку азот-вуглецевого обігу за органічної та інтенсивної системи удобрення в агроценозі коротко ротаційної зерно-просапної сівозміни на чорноземі опідзоленому сильнореградованому малогумусному в умовах Центрального Лісостепу України. Методи. Узагальнення результатів досліджень у польовому стаціонарному досліді, статистичний: дисперсійний, кореляційний аналізи параметрів продуктивності, структури фітомаси, якісних і кількісних статей балансу азоту, вуглецю. Результати. За органічної системи удобрення винос $\mathrm{N}$ зростає до 0,25 одиниць на одиницю ємності балансу азоту, що в 1,47 рази вище, а загальна 
витрата $\mathrm{N}$ зросла в 1,10 рази $(0,31$ одиниць на одиницю ємності балансу азоту) відносно інтенсивної системи удобрення, але за менших значень статей балансу азоту в агроценозі. При цьому виявлено прямі сильні кореляційні зв'язки між виходом кормових одиниць і умістом органічного вуглецю у структурних складових загальної фітомаси: 3 органічним вуглецем в основній продукції та кореневої маси $-\mathrm{R}=0,86-0,88 \pm$ $\pm 0,02 ; \mathrm{R}^{2}=0,74-0,77$, а з умістом органічного вуглецю у побічній продукції і нетоварній загальній фітомасі зв'язок з виходом кормових одиниць був на рівні прямої середньої кореляції: $\mathrm{R}=0,58-0,65 \pm 0,02 ; \mathrm{R}^{2}=0,34-0,43$. Зростання виходу кормових одиниць супроводжувалося зниженням ємності балансу азоту в 1,32 рази відносно інтенсивної системи удобрення. Висновки. Встановлено, що за органічної системи удобрення співвідношення органічного вуглецю до $\mathrm{N}$ в агроценозі короткоротаційної сівозміни $є$ найбільш оптимальним і наближається до $30: 1$, що є найбільш вигідним для гуміфікації побічної продукції і зниження інтенсивності мінералізації гумусу. Обмежувальним чинником в обігу органічного вуглецю і $\mathrm{N}$ за органічної системи $є$ ємність балансу, яка за органічної системи удобрення істотно поступається ємності балансу органічного вуглецю та $\mathrm{N}$ за інтенсивної системи удобрення, що негативно впливало на продуктивність сівозміни.

Ключові слова: баланс органічного вуглецю та азоту, ємність балансу, продуктивність, короткоротаційна сівозміна, кореляційний аналіз.

\section{Азот-углеродный оборот в агроценозах при различных системах удобрения}

\author{
А. В. Демиденко ${ }^{1}$ В. А. Величко ${ }^{2}$
}
${ }^{1}$ Черкасская государственная сельскохозяйственная опытная станция ННЦ «Институт земледелия»
${ }^{2}$ Смелянского района Черкасской области, Украина ННЦ «Институт почвоведения и агрохимии им. А.Н. Соколовского НААН» г. Харьков, Украина

e-mail: smilachiapv@ukr.net, agrovisnyk@ukr.net

Цель. Провести сравнительную оценку азот-углеродного оборота при органической и интенсивной системы удобрения в агроценозах короткоротационного зерно-пропашного севооборота на черноземе оподзоленном в условиях Центральной Лесостепи Украины. Методы. Обобщение результатов исследований в полевом стационарном опыте, статистический: дисперсионный, корреляционный анализ параметров производительности, структуры фитомассы и качественных и количественных статей баланса азота, углерода. Результаты. При органической системе удобрения вынос $\mathrm{N}$ возрастает до 0,25 единиц на единицу емкости баланса азота, что в 1,47 раза выше, а общий расход
$\mathrm{N}$ вырос в 1,10 раза $(0,31$ единиц на единицу емкости баланса азота относительно интенсивной системы удобрения, но при меньших значениях статей баланса азота в агроценозах. При этом выявлено прямые сильные корреляционные связи между выходом к.е. и содержанием органического углерода в структурных составляющих общей фитомассы: с органическим углеродом в основной продукции и органическим углеродом корневой массы $-\mathrm{R}=0,86-0,88 \pm 0,02$; $\mathrm{R}^{2}=0,74-0,77$, а с содержанием органического углерода в побочной продукции и нетоварной общей фитомассы связь с выходом к. е. была на уровне прямой корреляции: $\mathrm{R}=0,58-0,65 \pm 0,02 ; \mathrm{R}^{2}=0,34-0,43$. Рост выхода к.е. сопровождался снижением емкости баланса азота в 1,32 раза относительно интенсивной системы удобрения. Выводы. Установлено, что при органической системе удобрения соотношение органического углерода к $\mathrm{N}$ в агроценозе короткоротационного севооборота есть наиболее оптимальным и приближается к $30: 1$, что является наиболее выгодным для гумификации побочной продукции и снижению интенсивности минерализации гумуса. Ограничивающим фактором в кругообороте органического углерода и $\mathrm{N}$ при органической системе удобрения является емкость баланса, которая при органической системе удобрения существенно уступает емкости баланса органического углерода и $\mathrm{N}$ при интенсивной системе удобрения, что негативно влияло на продуктивность севооборота.

Ключевые слова: баланс органического углерода и азота, емкость баланса, производительность, короткоротационный севооборот, корреляционный анализ.

\section{REFERENCES}

1. Semenov VM, Lebedeva TN. The problem of carbon in sustainable agriculture: agrochemical aspects. Agrohimiya, 2015;(11):3-12.

2. Doran JW, Coleman DC, Bezdicek DF, Stewart BA. Defining soil quality for a sustainable environment. Soil Science Society of America and American Society of Agronomy., 1994:3-22. doi: 10.2136/sssaspecpub35. frontmatter.

3. Doran JW, Sarrantonio M, Liebig MA. Soil health and sustainability. Adv. Agron. 1996;56:1-54. doi. org/10.1016/S0065-2113(08)60178-9.

4. Golubyatnikov LL, Mokhov II, Eliseev AV. Nitrogen Cycle in the Earth Climatic System and Its Modeling. Izvestiya RAN. Fizika atmosferi i okeana, 2013:49(3):255-70.

5. Menyailo OV, Matvienko AI, Makarov MI, Cheng C-H. Nitrogen effects on the carbon cycle in forest ecosystems: a review. Lesovedenie, 2018;(2):143-59. doi: 10.7868/ S0024114818020067.

6. Demydenko OV, Shapoval IS, Bojko PI, Velychko $V A$. Carbon-nitric turnover in agrocnoses of crop rotations. Bulletin of Agricultural Science, 2018;(9):6472. doi.org/10.31073/agrovisnyk201809-10. 


\section{DEMYDENKO et al.}

7. Semenov VM, Khodzhaeva AK. Agroecological functions of plant residues in soil. Agrohimiya, 2006;(7):63-81.

8. Kuznetsova TV, Khodzhaeva AK, Semenova NA, Ivannikova LA, Semenov VM. Nitrogen mineralizationimmobilization turnover in soil under different decomposable organic matter supplies. Agrohimiya, 2006; (6):5-12.

9. Semenov VM, Tulina AS .Comparative Characterization of the Mineralizable Organic Matter Pool in the Soils of Natural and Agricultural Ecosystems. Agrohimiya, 2011;(12):53-63.

10. Kuznetsov AM, Ivannikova LA, Semin VYu, Nadezhkin $S M$, Semenov VM. Impact of long-term application of fertilization on biological quality of organic substance of leached chernozem. Agrohimiya, 2007;(11):21-31. [in Russian].

11. Semenov VM. Modern problems and perspectives of nitrogen agrochemistry. Problemy agrohimii i ekologii. 2008(1):55-63. [in Russian]

12. Hart SC, Nason GE, Myrold DD, Perry DA. Dynamics of gross nitrogen transformations in an oldgrowth forest: The Carbon connection. Ecology, 1994:75(4):880-91. doi: $10.2307 / 1939413$.

13. Oehl F, Frossard E, Fliessbach A, Dubois D, Oberson $A$. Basal organic phosphorus mineralization in soils under different farming systems. Soil Biol. Biochem. 2004;36(4):667-675. doi.org/10.1016/j.soilbio. 2003.12.010.

14. Richardson AE, Simpson RJ. Soil Microorganisms Mediating Phosphorus Availability. Plant Physiol., 2011;156: 989-96. doi: 10.1104/pp.111.175448.

15. Achat DL, Morel C, Bakker MR, Augusto L, Pellerin S, Gallet-Budynek A, Gonzalez M. Assessing turnover of microbial biomass phosphorus: combination of an isotopic dilution method with a mass-balance model. Soil Biol. Biochem., 2010;42(12):2231-40. doi:10.1016/j. soilbio.2010.08.023.

16. Janzen HH, Olson BM, Zvomuya F, Larney FJ, Ellert $B H$. Long-term field bioassay of soil quality. Prairie Soils Crops J., 2012;5:165-8.

17. Kurschens $M$. Importance of soil organic matter (SOM) for biomass production and environment (a review). Arch. Agronom. Soil Sci., 2002;48(2):89-94. https://doi. org/10.1080/03650340214162.

18. Kuzyakov Y, Gavrichkova O. Time lag between photo- synthesis and carbon dioxide efflux from soil: a review of mechanisms and controls. Glob. Change Biol., 2010;16(12):3386-406. https://doi.org/10.1111/j.13652486.2010.02179.x.

19. Kudeyarov VN, Biel K, Blagodatsky SA, Semenov VM, Dem'yanova EG, Dorodnikov $M V$. Fertilizing effect of the increasing $\mathrm{CO}_{2}$ concentration in the atmosphere. Euras. Soil Sci., 2006;39(1):S6-S14. doi: 10.1134/ S1064229306130035.

20. Lawlor DW, Mitchell RAC. The effects of increasing $\mathrm{CO}_{2}$ on crop photosynthesis and productivity: a review of field studies. Plant Cell Environ., 1991;14:807-18. doi. org/10.1111/j.1365-3040.1991.tb01444.x.

21. Scholes MC, Powlson D, Tian G. Input control of organic matter dynamics. Geoderma, 1997;79(1):25-47. doi.org/ 10.1016/S0016-7061(97)00037-2.

22. McGrath JM, Lobell DB. Regional disparities in the $\mathrm{CO}_{2}$ fertilization effect and implications for crop yields. Environ. Res. Lett., 2013;8:9 p. doi:10.1088/1748-9326/ $8 / 1 / 014054$.

23. Lenka NK, Lal R. Soil-related constraints to the carbon dioxide fertilization effect. Critic. Rev. Plant Sci., 2012;31(4):342-57. doi.org/10.1080/07352689.2012.67 4461.

24. Edmeades DC. The long-term effects of manures and fertilizers on soil productivity and quality: a review. Nutr. Cycl. Agroecosyst., 2003;66(2):165-80. doi.org/ 10.1023/A:1023999816690.

25. Alvarez $R$. A review of nitrogen fertilizer and conservation tillage effects on soil organic carbon storage. Soil Use Manag., 2005;21(1):38-52. doi. org/10.1111/j.1475-2743.2005.tb00105.x.

26. Sharkov IN, Danilova AA. Effect of different agricultural technologies on soil organic matter content. Agrohimiya, 2010;(12):72-81.

27. Zinyakova NB, Khodzhaeva AK, Tulina AS, Semenov VM. Active organic matter in the gray forest soil of arable and fallow lands. Agrohimiya, 2013;(9):3-14.

28. Lenka NK, Lal R. Soil-related constraints to the carbon dioxide fertilization effect. Critic. Rev. Plant Sci. 2012; 31:342-57.

29. Demydenko OV, Zapasna YuM, Velychko VA. Sequestration of carbon oxide in different fertilization systems in agrocenoses. Agric. Sci. Pract., 2018;5(2):37-51. doi: 10.15407/agrisp5.02.037. 